\title{
Faunal response to morphology and water circulation of a sandy beach with cusps
}

\author{
Anton McLachlan ${ }^{1 *}$ and Patrick Hesp ${ }^{2}$ \\ ${ }^{1}$ CSIRO Fisheries Laboratory, P.O. Box 20, North Beach, W.A. 6020, Australia \\ ${ }^{2}$ Department of Agriculture, Jarrah Road, South Perth, W.A. 6151, Australia
}

\begin{abstract}
Morphology of, and water circulation on, a reflective microtidal beach with 26 to $32 \mathrm{~m}$ cusps are described. The distribution of meiofauna, macrofauna, zooplankton and fishes was quantified and related to features such as cusp horns and bays, and rip currents. Meiofauna avoided the horn and concentrated on the sides of the rip current running down the cusp bay, although different taxa were concentrated at different intertidal levels. Macrofauna filter feeders, 2 donacid bivalves, were concentrated in cusp bays and showed no tidal migrations. A hippid crab, which is a scavenger, occurred throughout the cusp system and exhibited tidal migrations. Zooplankton, dominated by amphipods and mysids, was more abundant inside the 'surf zone' than outside. Within the surf zone it showed a weak tendency to concentrate off cusp horns. Fishes were netted in highest numbers around rip heads in cusp bays, and were less abundant in the surf off cusp horns. The reasons for these distribution patterns are discussed.
\end{abstract}

\section{INTRODUCTION}

Wave-dominated marine beaches are amongst the most physically controlled environments. Lacking the obvious spatial complexity of other environments (e.g. rocky shores, coral reefs), their physical structure must be entirely the result of the arrangement and interactions of the primordial elements of sand and water. Structure is provided by the morphology and water circulation of the beach and surf zone, and habitats or spatial niches in such systems must be defined in terms of sedimentary features and water movement. Evaluating the effects on the fauna of features such as beach profile, rip currents and bars is difficult, if not impossible, in high energy beaches, because of the large scale and dynamic nature of the environment. However, on the low energy, microtidal beaches of Western Australia, which often exhibit a cusp circulation, the whole range of conditions from cusp horn to bay and including a mini-rip current and break point, falls within an area ca. $30 \times 20 \mathrm{~m}$. Cusps are scallops or undulations along the beach which break the beach face into a series of bays and promontories or horns. These beaches therefore provide an ideal 'microcosm'

- Present address: Department of Zoology, University of Port Elizabeth, P.O. Box 1600, Port Elizabeth, 6000, South Africa in which to base a primary assessment of the faunal response to a variety of beach/surf zone features.

The main components of the beach surf zone area are the interstitial fauna, macrobenthos, zooplankton and fishes. While there are many studies which have examined the distribution of macrofauna and meiofauna in relation to parameters such as particle size and tidal height, there has been no attempt to relate them to morphology and dynamic features (for review see McLachlan, 1983) except for a correlation between macrofaunal diversity and abundance and beach face slope shown by McLachlan et al. (1981). This correlation indicated that richest macrofauna should occur on beaches with flattest slopes, i.e. more dissipative beaches. Very little work has been done on surf zone zooplankton (McLachlan, 1983), but Clutter (1967) and Wooldridge (1983) have suggested that mysids might concentrate near the heads of rip currents. The response of fishes to surf zone morphology and dynamics has also not been assessed, although Lasiak (1982) has shown a correlation between fish assemblages in the surf zone and wind conditions, the latter having a partial controlling effect on wave action.

Patchiness has been shown in many beach populations (Efford, 1965; Cubit, 1969; Dillery and Knapp, 1969; Brown, 1971; Perry, 1980; Bally, 1983) but this 
has not been related to surf zone morphodynamics except in the case of surf zone phytoplankton blooms which are associated with rip currents (McLachlan and Lewin, 1981). Hill and Hunter (1976) have examined the interaction of biological and geological processes in beach and nearshore environments. Aggregations of sand crabs, Emerita sp., have been suggested to be related to beach cusps (Dillery and Knapp, 1969), but no evidence has been provided for this. Aggregations of sand crabs have, indeed, been regarded as having a biological cause. Bally (1983) discussed the patchiness of beach fauna but provided no functional explanation, while Grant (1981) concluded that faunal distribution on a sand flat was related to an active preference for ripple crests.

Patchiness in beach fauna is thus well documented but poorly explained, and functional relations between faunal distribution and beach morphology and water circulation dynamics have been ignored and neglected. The aim of this study was to quantify the distribution fauna in relation to the physical features of a reflective beach with marked cusps and cusp circulation, as a first attempt to decipher the functional relations between beach/surf zone morphology and dynamics and faunal ecology.

\section{STUDY AREA}

The beach selected had a fairly rich macrofauna, relative to other local reflective (steep) beaches, and well developed cusps at most times, although cusp circulation was damped or destroyed by local wind wave activity during rough weather or alongshore winds. Sorrento beach is just north of Perth, Western Australia at $31^{\circ} 50^{\prime} \mathrm{S} 115^{\circ} 45^{\prime} \mathrm{E}$. Being protected behind offshore limestone reefs, it receives low to moderate energy waves. Mean height of larger waves just off the beach is $0.4 \mathrm{~m}$ and maximum wave height is commonly 1.0 to $1.5 \mathrm{~m}$ as opposed to $1.4 \mathrm{~m}$ and 2.0 to $2.5 \mathrm{~m}$, respectively, offshore (Steedman et al., 1977). Modal wave period is $6.5 \mathrm{~s}$. The coast is microtidal with mixed tides dominated by diumal constituents, although some semidiurnal constituents occur during 'neap' phases (Hodgkin and di Lollo, 1958). Maximum tide range is $0.9 \mathrm{~m}$ and minimum $0.1 \mathrm{~m}$ with a daily mean maximum of $0.38 \mathrm{~m}$. Because of this small tide range meteorological effects can override tides (Eliot et al., 1982). The beach material at Sorrento is medium sand of approximately $300 \mu \mathrm{m}$ mean particle diameter and $30 \%$ calcium carbonate (McLachlan et al., 1984). The beach has cusps with 26 to $32 \mathrm{~m}$ spacings and is backed by a high foredune ridge which is eroding in places.

\section{METHODS}

Several detailed topographic profiles were measured down cusp horns, bays and intermediate areas using a dumpy level. Sand samples were collected at high tide, mid tide and step (breakpoint) positions within bays and on horns, and sieved at $0.5 \Phi$ intervals. Swash and backwash phenomena were observed and timed by stopwatch, and mean circulation patterns were elucidated utilising rhodamine dye and photography.

Measurements of the wrack deposited on cusp horns and bays were made by systematic collection and weighing of drift line material along two horn/bay systems. The amount of suspended material in the water column at 1 to $1.5 \mathrm{~m}$ depth in rip heads off bays, and off horns was evaluated by taking twenty 11 samples in each area, pooling and passing this through a $38 \mu \mathrm{m}$ screen, and drying the residue. Interstitial water samples were collected at $15 \mathrm{~cm}$ depth at a number of positions in a cusp bay/horn system and oxygen content measured using a Clark oxygen electrode.

Investigations of the fauna were divided into studies on meiofauna, macrofauna, zooplankton and fishes. For meiofauna three transect lines were surveyed, one along a horn, one along a bay and one in an intermediate position. At $4 \mathrm{~m}$ intervals along each line 4 replicate cores of $10 \mathrm{~cm}^{2}$ area were taken to $30 \mathrm{~cm}$ depth. In this way a grid covering half a horn/bay system was covered, an area $16 \times 14 \mathrm{~m}$. Additional samples were taken at $1 \mathrm{~m}$ depth in the surf zone to obtain an idea of meiofaunal densities below the intertidal zone in order to extrapolate results from the sampling grid. Each core sample was fixed and stained in $10 \%$ formalin rose bengal, extracted by four decants in fresh water and trapped on a $38 \mu \mathrm{m}$ mesh screen. Each sample was stored in $5 \%$ formalin and the animals counted.

The macrofauna was sampled by digging $0.1 \mathrm{~m}^{2}$ quadrats to $20 \mathrm{~cm}$ depth and passing the sand through a screen of $3.5 \mathrm{~mm}$ mesh. A series of such quadrats was taken at $1 \mathrm{~m}$ intervals along a number of transects down cusp horns, bays and intermediate areas. All fauna was identified, counted, and measured to $0.1 \mathrm{~mm}$ with sliding callipers. One series of transects was made during a very low and a very high tide (which coincided with rough weather) to see if any species exhibited tidal or other migrations.

Zooplankton was sampled after dark by vertical lifts of a net (of $1 \mathrm{~mm}$ mesh and $60 \mathrm{~cm}$ mouth diameter) in $1 \mathrm{~m}$ water off cusp horns and in rip heads in bays as well as $5 \mathrm{~m}$ outside the 'surf zone'. This was done on 2 separate occasions. Each sample was fixed in $10 \%$ formalin and counted separately.

Fishes were sampled using a seine net $15 \times 1 \mathrm{~m}$ with $1 \mathrm{~cm}$ stretched mesh and a collecting bag. Samp- 
ling was done during a moderate to rough evening from light through into dark and again during a calm to moderate early morning just after sunrise. On each occasion 6 pairs of discrete samples were taken from 6 cusp horn/bay systems, 1 off the horn and 1 off the bay (attempting to include the rip head) in each case. All species collected were identified and counted.

All results were analysed using standard chisquared and t-test statistics (Sokal and Rohlf, 1969).

\section{RESULTS}

\section{Beach morphology and water circulation}

Studies of surf zone-beach morphology and dynamics have lead to the recognition of a number of relatively distinct beach types (Short, 1979; Wright et al., 1979; Wright and Short, in press). These studies identify 2 extreme forms, reflective and dissipative beaches, between which exist a number of intermediate types. Each particular surf zone-beach morphology is produced by a certain combination of wave energy, sediment size and sediment abundance (Short and Hesp, 1982). In the short term a beach may experience a range of states, but in the long term the highest frequency of occurrence of a common or modal wave energy level will dictate a modal surf zone-beach state, i.e. the normal state of the beach.

Reflective beaches, such as Sorrento, are usually associated with either low wave energy, coarse grain size, deep nearshore or a combination of these. They are characterised by maximum subaerial sediment storage, a steep, cusped or bermed beach face, breakpoint step, low gradient nearshore profile, surging to plunging breakers, high run-up and maximum reflection of waves off the beach face with minimal dissipation.

In detail, Sorrento beach displays most of these characteristics. The beach consists of a narrow $(\sim 10 \mathrm{~m})$, gently sloping $\left(2^{\circ}\right)$, subaerial backshore, and relatively steep $\left(6^{\circ}\right)$, usually cusped, intertidal beach face. A pronounced step exists at the base of the beach face, this step forming at the position of collision between backwash and incident wave breaking. The surf zone seaward of the step is flat and commonly rippled, around 5 to $7 \mathrm{~m}$ wide, with a plunging breaker. The beach exhibited pronounced local variations in mean grain size within the intertidal zone and surf zone. Horn sands were notably coarser than bay sands, averaging 250,370 and $710 \mu \mathrm{m}$ for high tide, mid tide and step levels, respectively, compared to 200,250 and $250 \mu \mathrm{m}$ for the same positions within the bays.

Cusps, and their associated circulation, are domin- ant features of Sorrento beach. The cusps are characterised by wide scalloped bays and higher, narrow, flanking horns (Fig. 1). Cusp wavelength (horn to horn) was 26 to $32 \mathrm{~m}$ during experiments.

Swash cusps are formed in the intertidal by swash and backwash acting on the beach face. Recent research suggests that swash cusps are initiated by edge waves (longshore periodic gravity waves) interacting with incident waves (Wright et al., 1979; Inman and Guza, 1982). The net result of this interaction is that the superimposition of swash from incoming waves with the motion of sub-harmonic edge waves produces a systematic variation in run-up height along the beach face, which in turn produces a periodic erosional perturbation' (Inman and Guza, 1982, p. 134) and results in cusp bay formation.

Cusp circulation on Sorrento was identical to that illustrated in the sequential photographs of Fig. 1. The incident wave broke at or near the step, and the swash ran up the cusp horns ahead of swash run-up in the bay (Fig. 1a). Maximum uprush velocities on the horns peaked at $5 \mathrm{~m} \mathrm{~s}^{-1}$ compared to maximum uprush values of $2.5 \mathrm{~m} \mathrm{~s}^{-1}$ in the bay. This is primarily a function of slightly greater water depths off the horns compared to the bay. The swash ran up the cusp horns where it divided and flowed down the cusp bay. This backwash flow described the landward margin of the cusp bay (Fig. 1b). Divided backwash from two adjacent horns met in the centre of the cusp bay (Fig. 1c), and flowed seaward as an intense mini-rip (Fig. 1d). These stages are graphically illustrated in Fig. 2. This rip carried a discrete sediment load seaward through the incoming wave and rapidly formed a semi-circular plume in the surf zone, which gradually dissipated, the settling sediment forming a deltaic terrace. Maximum rip backwash velocities were $1.6 \mathrm{~m} \mathrm{~s}^{-1}$ in the bay. Since the horns are composed of coarser sediment, and the water table is lower, there is rapid infiltration of swash on the horns compared to the bay (cf. Chappell, 1978; McLachlan et al., 1984). However, although the horns received more swashes than the bay (3.9 swashes $\min ^{-1}$ on the horn vs. 2.9 in the bay), a point in the bay was covered with swash for a longer duration than an equivalent point on the horns $(34 \%$ of the total time in the bay vs. $25 \%$ on the horn) because swash duration averaged $3.8 \mathrm{~s}$ on horns and $7.0 \mathrm{~s}$ in bays.

Oxygen tensions in interstitial water were high in all samples (57 to $92 \%$ saturation) with the highest values in the cusp bay ( 87 to $92 \%$ ) and the lowest on the cusp horn $(57$ to $83 \%$ )

To summarise, the cusp horns are characterised by coarser sand, steeper slopes $\left(6\right.$ to $\left.7^{\circ}\right)$, maximum swash run-up at high velocities, lower water table, and high relative infiltration rates. The cusp bay is characterised by finer sand, lower slopes $\left(5^{\circ}\right)$, maximum backwash in 

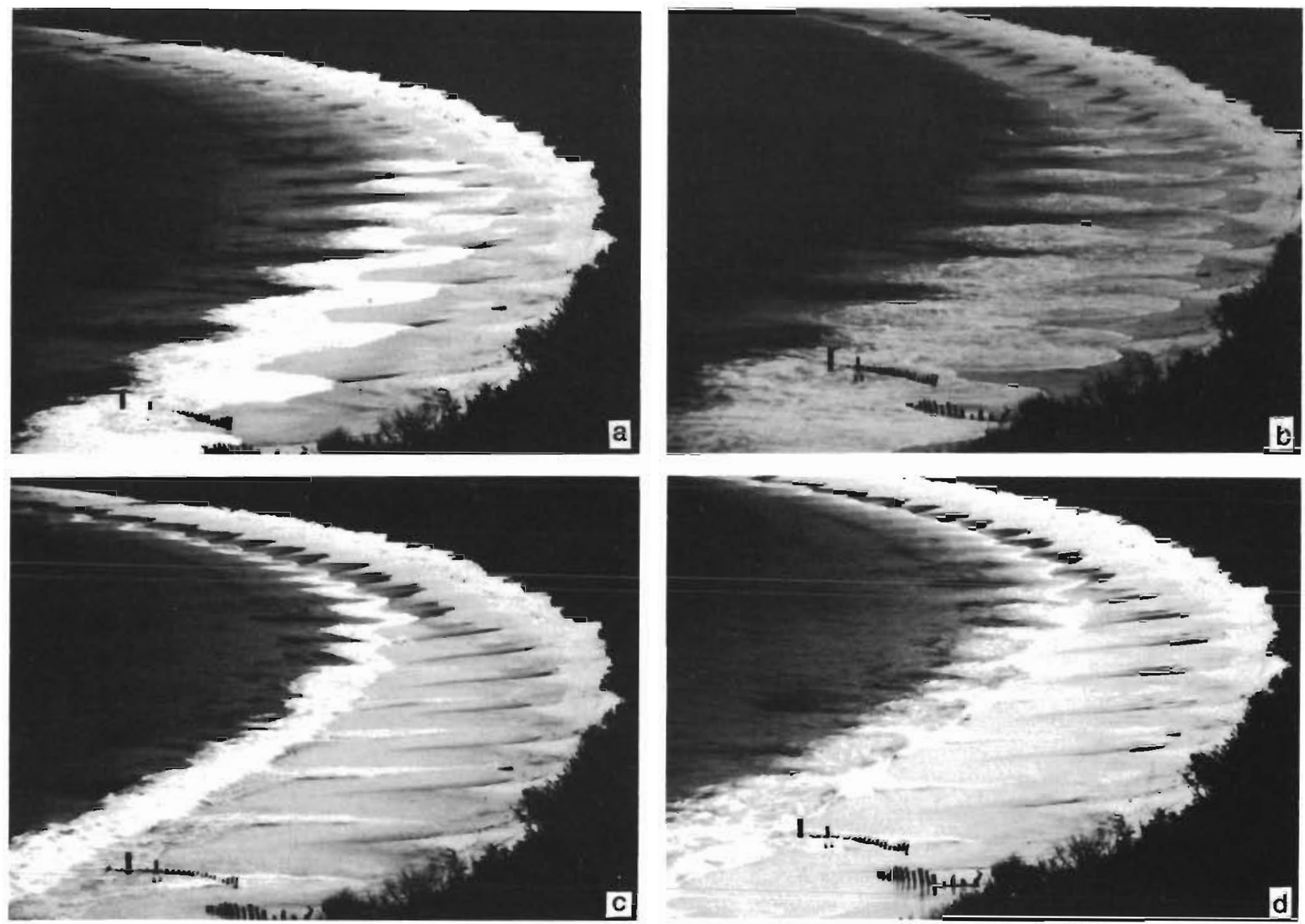

Fig. 1. Cusp circulations in a series of cusp systems on Vancouver beach, Albany, Western Australia. (a) Swash uprush on the horns exceeds bay uprush; (b) horn swash separates at maximum uprush and flows down adjacent bays; (c) horn swash collides in the mid bay region, forming an intense backwash rip down the bay axis; (d) bay rip collides with an incident wave at the base of the beach face and begins to form a rip head

a mini-rip form, high water table and low relative infiltration rates. The landward margins of bays also display high wrack concentrations compared to the horns $\left(190 \mathrm{~g} \mathrm{~m}^{-1}\right.$ on the bay margin, $40 \mathrm{~g} \mathrm{~m}^{-1}$ on the horn; $\left.\mathrm{X}_{1}^{2}=98, \mathrm{p}<0.001\right)$. The surf zone environment offshore from the horns is slightly deeper, the step is larger with coarser sand and suspended sediment (33 $\mathrm{mg}^{-1}$ ) is less than in the bays. The bay environment offshore has finer sand, flatter slope and is of less depth than the horns, and suspended sediment $\left(3,722 \mathrm{mg} \mathrm{l}^{-1}\right)$ is high in the rip plume (or head).

\section{Faunal distribution}

Meiofaunal results are shown in Fig. 3 together with topographic profiles of three lines sampled along the cusp horn, bay and intermediate positions. To aid visual interpretation of the results, contour lines of equal meiofaunal densities have been generated for a whole cusp horn/bay system by including mirror images of the intermediate and horn lines. The surf zone samples were taken approximately $5 \mathrm{~m}$ seaward of the lowest series of samples depicted in Fig. 3 and have not been shown, but were used to extrapolate the contour lines below the lowest sampling points.

All meiofauna groups exhibited lowest densities on the cusp horn and increased towards the bay, although no group reached maximum density along the bay mid (rip) line. In all cases there was a tendency for densities to peak to the side of the bay line, i.e. on the intermediate line or between the bay and intermediate lines. There was thus for each taxon a tendency to be more abundant in the top $30 \mathrm{~cm}$ in the bay and within this area to be concentrated on either side of the rip axis line. The main difference between the taxa was in the location of their maximum density bands across the beachface

Harpacticoids were concentrated lowest on the beachface and also exhibited the least avoidance of the horn. Polychaetes and oligochaetes were concentrated highest on the beachface and showed most avoidance 
Fig. 2. Diagrammatic illustration of cusp circulation. (a) maximum swash uprush on the cusp horns; (b) swash separation at maximum uprush; (c) formation of an intense rip in the cusp bay

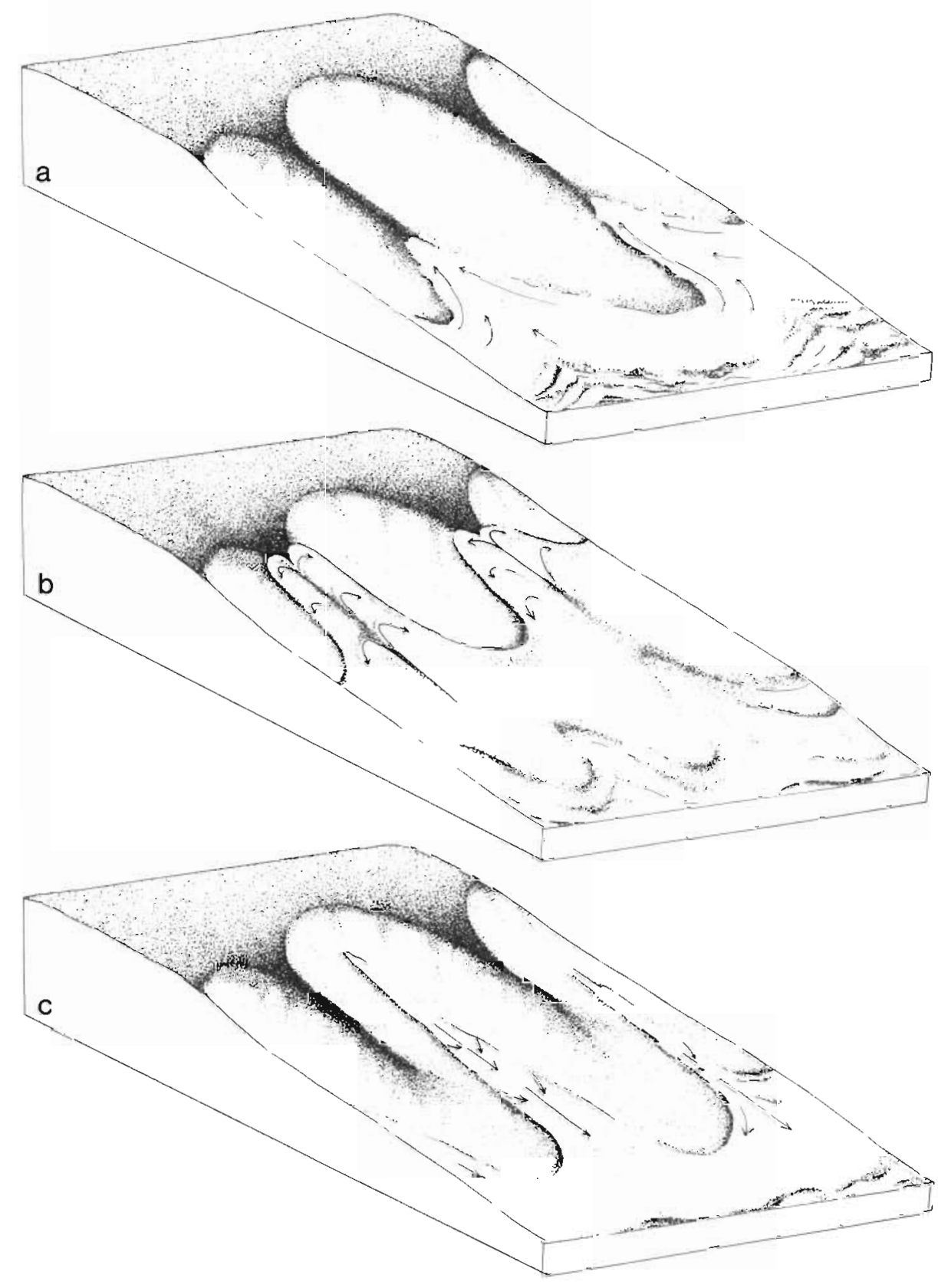

less, it is clear that there is active avoidance of the cusp horn with its turbulent surface, high interstitial flow rates, rapid drainage and large changes in moisture content. The weaker, but still marked avoidance of the bay mid line, associated with the rip current, cannot be due to low oxygen tension as interstitial oxygen levels were higher there. Neither can it be due to the finer sediment as nematodes, which have been shown to prefer finer sediments (Fricke and Fleming, 1983), also showed a slight decrease in numbers there. It would rather seem that avoidance is due to the intense currents and erosion caused by the rip itself.

Three macrofauna species were sampled in suffi- 


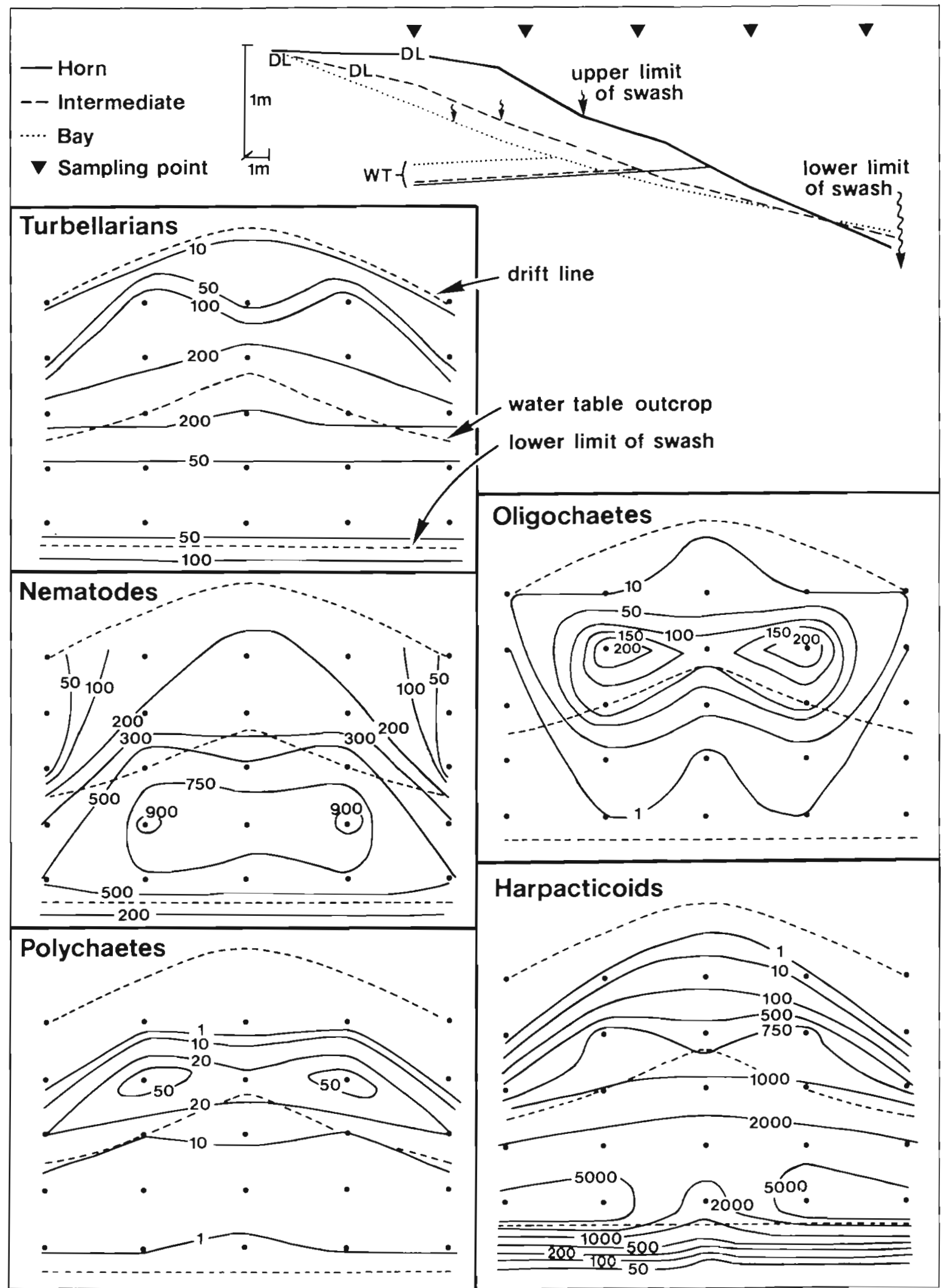

Fig. 3. Meiofaunal density (numbers $300 \mathrm{~cm}^{-3}$ ) distribution in a cusp system. Beach profile in upper diagram, meiofaunal densities in plan views in the other diagrams. Solid circles denote points at which 4 replicate samples were taken and broken lines denote the positions of the drift line (DL), water table (WT) outcrop and the bottom of the swash zone. Contour lines hand drawn by linear interpolation. Tide range $0.2 \mathrm{~m}$ isampling done during mid tide. Scale of sampling grid given in text 
cient numbers to allow evaluation of their distribution within a cusp system. These were the scavenging mole crab Hippa australis and the suspension feeding donacid bivalves Donacilla angusta and Donax faba. The distributions of these 3 species along a horn and a bay during a very high and a very low tide are illustrated in Fig. 4. These, and many other transect lines sampled, showed that $H$. australis occupied the highest position on the beachface, the upper swash zone, with $D$. angusta lower down around the low tide water table outcrop position, and $D$. faba lowest, generally coinciding with the lower limit of $D$. angusta. H. australis exhibited clear tidal migrations, moving 5 to $10 \mathrm{~m}$ downshore from high to low tide on both the horn and bay lines. The two bivalves exhibited no tidal migrations but did show some scattering from high to low tide, probably due to rough conditions and sampling error.

Table 1 summarises the results of all the macrofauna transects sampled. From these data chi-squared tests revealed significant preferences for the bays by Donacilla angusta and Donax faba under all conditions

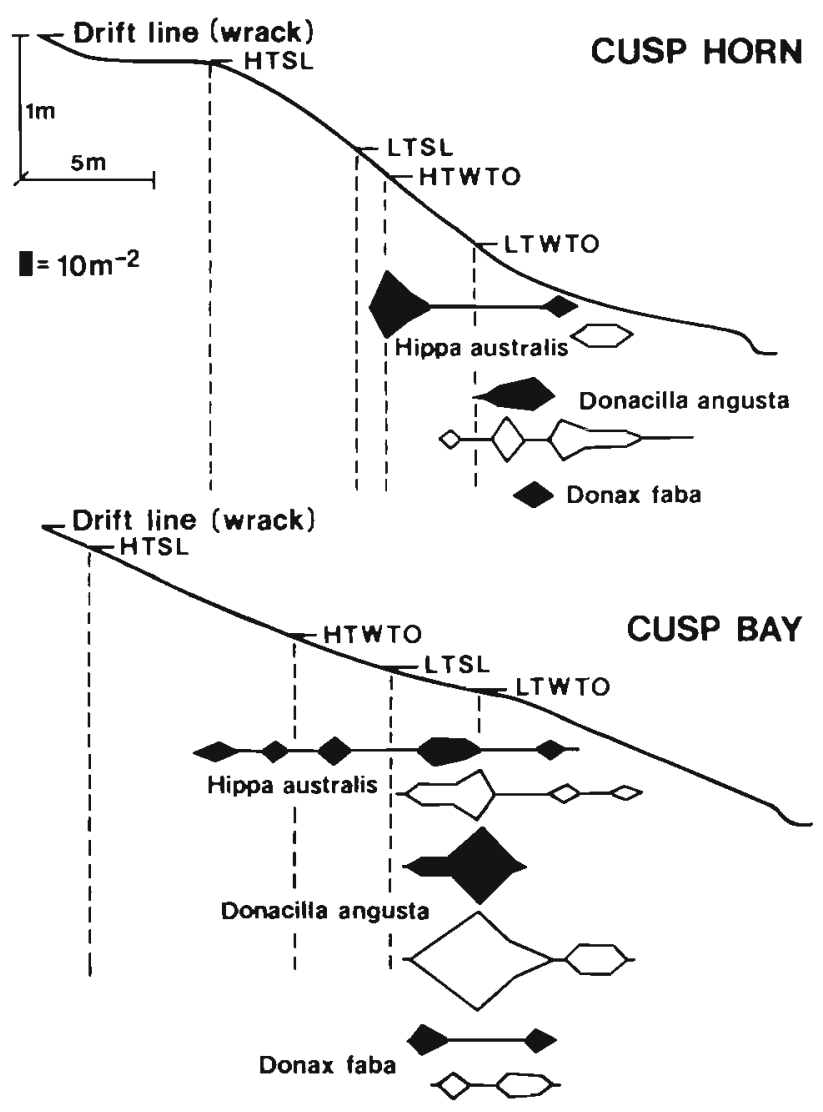

Fig. 4. Cusp horn and bay profiles during large tide (range = $0.6 \mathrm{~m}$ ) showing positions of high (HT) and low (LT) tide swash limits (SL) and water table outcrops (WTO), as well as distributions of the 3 dominant macrofauna species. Solid kites: high-tide macrofauna distribution; open kites: low-tide distribution $\left(\chi_{2}^{2}=13.5,25.9, \mathrm{p}<0.01\right)$, while preferences for horns by Hippa australis under calm/moderate conditions were not significant $\left(\chi_{2}^{2}=2.8, \mathrm{p}>0.1\right)$ and neither was their switching to a preference for bays under rough, erosional conditions $\left(\chi_{2}^{2}=1.0, p>0.1\right)$. The heterogeneity $\chi^{2}$ s for all 3 species were not significant $\left(\chi_{2}^{2}=\right.$ $2.1,1.1,0.1$, respectively, $\mathrm{p}>0.1$ ) indicating that there were no significant variations within replicates resulting from aggregation or sampling error. No significant differences in the sizes of bivalves collected from the 3 areas could be obtained, but $H$. australis individuals were significantly larger (t-test, $p<0.01$ ) on horns than in bays using the data from the calm/moderate periods only. Mean carapace width of individuals on the horns was $7.6 \mathrm{~mm}$ ( $\mathrm{n}=21$, range 5.1 to $12.0 \mathrm{~mm}$ ) and $6.0 \mathrm{~mm}$ in the bays ( $\mathrm{n}=17$, range 4.6 to $8.8 \mathrm{~mm}$ ). More size differences may have been found had a finer mesh sieve been used and juveniles collected, but the presence of coarse sand made this impractical.

If all the data from calm and rough conditions are pooled, both bivalves still showed clear concentrations in the bays $\left(\chi_{2}^{2}=22\right.$ (Donacilla angusta), 32 (Donax faba), $\mathrm{p}<0.001$ ) while Hippa australis was slightly more abundant in intermediate areas (mean = $48 \mathrm{~m}^{-1}$ ), followed by horns (mean $=40 \mathrm{~m}^{-1}$ ) and bays (mean $=35 \mathrm{~m}^{-1}$ ), although these differences were not significant $\left(\chi_{2}^{2}=1.7, \mathrm{p}>0.1\right)$.

Hippa australis is the most mobile of the 3 species and can burrow rapidly in a range of substrates, taking 1 to $2 \mathrm{~s}$ for burial at $20^{\circ} \mathrm{C}$ (laboratory obs.), while both bivalves rely on swash to move them about the beachface and burrow more slowly, burial taking 7 to $10 \mathrm{~s}$ in Donacilla angusta and 10 to $15 \mathrm{~s}$ in Donax faba. Hippa australis can thus roam the shore at will and actively move to favoured areas, while the bivalves would tend to be moved towards the bay centre by the movement of swash coming in from the horns. The bay would also provide better conditions for filter feeding as there is greater coverage by water, and gentler swash action resulting from the more even gradient. During storm wind wave events, when the horns erode away and swash is more evenly distributed along the beachface, the bivalves may be more evenly distributed. They may aggregate in bays again during calm conditions when renewed cusp development concentrates swash in these areas.

The results of the zooplankton samples are summarised in Table 2. Accurate positioning of the net after dark was difficult and cusp bay hauls could seldom be placed in the centre of the rip head with certainty. Samples were dominated by amphipods and mysids with polychaetes, isopods and fish larvae in low numbers. On the first occasion, bay and horn samples were very similar, the slightly higher numbers in the bay not being significant $\left(\chi_{1}^{2}=0.13, p>0.1\right)$, while hete- 
Table 1. Summary of 26 transects sampled for macrofauna. Total numbers given for 1 running m of shoreline

\begin{tabular}{|c|c|c|c|c|}
\hline Species & Position & Conditions & $\begin{array}{c}\text { No. transects } \\
\text { sampled }\end{array}$ & $\begin{array}{l}\text { Mean numbers } \\
\quad \pm \mathrm{SD}\left(\mathrm{m}^{-1}\right)\end{array}$ \\
\hline Hippa australis & Horn & $\mathrm{Calm} /$ moderate tide & 6 & $54 \pm 34$ \\
\hline Hippa australis & Intermediate & Calm/moderate tide & 6 & $48 \pm 46$ \\
\hline Hippa australis & Bay & Calm/moderate tide & 6 & $33 \pm 18$ \\
\hline Hippa australis & Horn & Rough/large tide & 4 & $20 \pm 12$ \\
\hline Hippa australis & Bay & Rough/large tide & 4 & $38 \pm 3$ \\
\hline Donacilla angusta & Horn & Calm/moderate tide & 6 & $20 \pm 12$ \\
\hline Donacilla angusta & Intermediate & Calm/moderate tide & 6 & $28 \pm 18$ \\
\hline Donacilla angusta & Bay & Calm/moderate tide & 6 & $56 \pm 16$ \\
\hline Donacilla angusta & Horn & Rough/large tide & 4 & $33 \pm 20$ \\
\hline Donacilla angusta & Bay & Rough/large tide & 4 & $73 \pm 21$ \\
\hline Donax faba & Horn & Calm/moderate tide & 6 & $0 \pm 0$ \\
\hline Donax faba & Intermediate & Calm/moderate tide & 6 & $5 \pm 8$ \\
\hline Donax faba & Bay & $\mathrm{Calm} /$ moderate tide & 6 & $19 \pm 28$ \\
\hline Donax faba & Horn & Rough/large tide & 4 & $3 \pm 3$ \\
\hline Donax faba & Bay & Rough/large tide & 4 & $25 \pm 2$ \\
\hline
\end{tabular}

Table 2. Results of 30 zooplankton tows in surf zone shallows. Volume sampled haul $\mathbf{l}^{-1}=0.28 \mathrm{~m}^{3}$

\begin{tabular}{|c|c|c|c|c|c|c|}
\hline \multirow[t]{2}{*}{ Position } & \multirow{2}{*}{$\begin{array}{c}\text { No. } \\
\text { samples }\end{array}$} & \multirow[t]{2}{*}{ Conditions } & \multicolumn{4}{|c|}{ Numbers haul ${ }^{-1}($ mean $\pm S D)$} \\
\hline & & & Amphipods & Mysids & Others & Total \\
\hline Off horn & 6 & Moderate & $23 \pm 11$ & $6 \pm 4$ & 1 & $30 \pm 15$ \\
\hline Off bay & 6 & Moderate & $29 \pm 7$ & $3 \pm 2$ & 0.5 & $33 \pm 9$ \\
\hline Off horn & 6 & Fairly calm & $8 \pm 9$ & $3 \pm 5$ & 0.5 & $11 \pm 14$ \\
\hline Off bay & 6 & Fairly calm & $4 \pm 3$ & $3 \pm 4$ & 0.5 & $8 \pm 5$ \\
\hline Outside 'surf zone' & 6 & Fairly calm & $1 \pm 1$ & $1 \pm 1$ & 0 & $3 \pm 2$ \\
\hline
\end{tabular}

rogeneity was significant $\left(\chi_{5}^{2}=12.5, \mathrm{p}<0.05\right)$. On the second occasion slightly calmer conditions allowed better siting of sampling points. Horn samples were significantly richer than bay samples $\left(\chi_{1}^{2}=4.24\right.$, $\mathrm{p}<0.05)$ and heterogeneity was also significant $\left(\chi_{5}^{2}=\right.$ $11.4, \mathrm{p}<0.05)$. Both horn and bay samples were very significantly richer than samples taken outside the surf zone $\left(\chi_{1}^{2}=32.3, \mathrm{p}<0.001\right.$ and $\chi_{1}^{2}=14.5, \mathrm{p}<0.001$, respectively), with heterogeneity significant in the case of the horn samples only $\left(\chi_{5}^{2}=15.3, p<0.01\right.$ and $\chi_{5}^{2}=6.8, \mathrm{p}>0.1$, respectively). Pooling all the horn and all the bay data yields no significant difference $\left(\chi_{1}^{2}=0\right)$. There is thus clearly more zooplankton in the surf zone than offshore, and this zooplankton is fairly evenly distributed amongst bay and horn areas in the cusp circulation, with a tendency on one occasion to be richer in the horn area. Variability between samples is high.

Female mysids with brood pouches containing eggs or young generally occur closest inshore, apparently to avoid turbulence (Wooldridge, 1983). During the first sampling, approximately equal numbers of female mysids with full brood pouches occurred off horns and bays ( 5 and 7 , respectively) but on the second occasion there were 14 off bays, 2 off horns and none outside the surf zone, these differences being highly significant $\left(\chi_{2}^{2}=21.7, p<0.001\right)$.

Seine netting results are summarised in Table 3. Nine species of benthic and planktonic feeding fishes were recorded. Of these Hyperlophus vittatus, the whitebait, and Torquigener pleurogramma, the puf ferfish, were recorded principally in shoals in rip heads off bays, while the other species were collected essentially as solitary individuals. Bays provided consistently richer hauls than horns, both in terms of total fish numbers (means 104.6 vs. 5.5 haul $^{-1}$ ) and species richness (means 2.7 vs. 1.7 species haul ${ }^{-1}$ ). Using $\chi^{2}$ tests on these data, significant differences were found between horns and bays for both morning $\left(\chi_{1}^{2}=118\right.$, $p<0.001)$ and evening $\left(\chi_{1}^{2}=953, p<0.001\right)$ hauls, and between morning and evening hauls for both horns $\left(\chi_{1}^{2}=27, \quad p<0.001\right)$ and bays $\left(\chi_{1}^{2}=727\right.$, $p<0.001)$. The heterogeneity $\chi^{2}$ was also significant $\left(\chi_{11}^{2}=95, p<0.001\right)$ reflecting the large variations between hauls, an inevitability when shoaling species are encountered. Pooling all the data reveals a significant difference between horn and bay hauls $\left(\chi_{1}^{2}=1,068, p<0.001\right)$.

These data reveal that while the surf zone fish assemblage' is highly variable in time and space, there 
Table 3. Results of seine hauls in surf zone shallows off cusp horns and bays during early morning and late evening B: principally benthic feeding fishes; P: principally plankton feeding fishes (Lenanton, pers. comm.)

\begin{tabular}{|c|c|c|c|c|c|c|c|c|c|c|c|c|c|}
\hline \multirow[t]{2}{*}{ Species } & \multicolumn{6}{|c|}{ Evening hauls } & \multicolumn{6}{|c|}{ Morning hauls } & \multirow{2}{*}{$\begin{array}{c}\text { Mean nos. } \\
\text { haul }\end{array}$} \\
\hline & 1 & 2 & 3 & 4 & 5 & 6 & 1 & 2 & 3 & 4 & 5 & 6 & \\
\hline \multicolumn{14}{|c|}{ HORN } \\
\hline Crapatalus arenarius ${ }^{(\mathrm{B})}$ & 2 & 0 & 3 & 1 & 1 & 2 & 0 & 0 & 0 & 0 & 0 & 0 & 0.8 \\
\hline Pelsartia humeralis $(\mathrm{B}+\mathrm{P})$ & 1 & 0 & 0 & 0 & 3 & 1 & 0 & 0 & 0 & 1 & 0 & 0 & 0.5 \\
\hline Sillago bassensis ${ }^{(\mathrm{B})}$ & 0 & 0 & 0 & 0 & 0 & 4 & 0 & 0 & 0 & 0 & 0 & 0 & 0.3 \\
\hline Hyperlophus vittatus ${ }^{(\mathrm{P}+\mathrm{B})}$ & 0 & 0 & 25 & 1 & 0 & 1 & 0 & 0 & 0 & 0 & 0 & 0 & 2.3 \\
\hline Spratelloides robustus ${ }^{(\mathrm{P})}$ & 0 & 0 & 0 & 0 & 0 & 0 & 0 & 0 & 0 & 0 & 0 & 0 & 0 \\
\hline Schuetta woodwardi? (P) & 0 & 0 & 0 & 0 & 4 & 2 & 0 & 0 & 0 & 0 & 0 & 0 & 0.5 \\
\hline Sillago schomburgkii ${ }^{(\mathrm{B})}$ & 0 & 0 & 0 & 0 & 1 & 0 & 0 & 0 & 0 & 0 & 0 & 0 & 0.1 \\
\hline Torquigener pleurogramma ${ }^{(\mathrm{B})}$ & 0 & 0 & 0 & 0 & 0 & 0 & 1 & 1 & 9 & 0 & 0 & 0 & 0.9 \\
\hline Trygonorhina fasciata ${ }^{(\mathrm{B})}$ & 0 & 0 & 0 & 0 & 0 & 0 & 0 & 0 & 0 & 0 & 0 & 0 & 0 \\
\hline Total: & 3 & 0 & 28 & 2 & 9 & 10 & 1 & 1 & 9 & 1 & 0 & 0 & 5.5 \\
\hline \multicolumn{14}{|c|}{ BAY } \\
\hline Crapatalus arenarius & 2 & 1 & 0 & 3 & 1 & 2 & 0 & 2 & 2 & 0 & 0 & 0 & 1.1 \\
\hline Pelsartia humeralis & 2 & 0 & 0 & 0 & 0 & 0 & 1 & 2 & 0 & 2 & 1 & 1 & 0.8 \\
\hline Sillago bassensis & 1 & 0 & 0 & 0 & 0 & 1 & 2 & 2 & 0 & 0 & 0 & 0 & 0.5 \\
\hline Hyperlophus vittatus & 0 & 879 & 200 & 2 & 2 & 0 & 0 & 0 & 0 & 0 & 0 & 0 & 90.3 \\
\hline Spratelloides robustus & 0 & 3 & 0 & 0 & 0 & 0 & 0 & 0 & 0 & 0 & 0 & 0 & 0.3 \\
\hline Schuetta woodwardi? & 0 & 0 & 0 & 0 & 1 & 3 & 0 & 0 & 0 & 0 & 0 & 0 & 0.3 \\
\hline Sillago schomburgkii & 0 & 0 & 0 & 0 & 0 & 0 & 0 & 0 & 0 & 0 & 0 & 0 & 0 \\
\hline Torquigener pleurogranma & 0 & 0 & 0 & 0 & 0 & 0 & 89 & 4 & 2 & 35 & 2 & 2 & 11.2 \\
\hline Trygonorhina fasciata & 0 & 0 & 0 & 0 & 0 & 0 & 1 & 0 & 0 & 0 & 0 & 0 & 0.1 \\
\hline Total: & 5 & 883 & 200 & 5 & 4 & 6 & 93 & 10 & 4 & 37 & 3 & 3 & 104.6 \\
\hline
\end{tabular}

is a significant tendency for fishes to concentrate off bays in the area of turbid water formed by rip heads. (Only 2 species were collected in greater numbers off horns than bays, the pomphrid Schuetta woodwardi and the western sand whiting Sillago schomburgkii. These were recorded as 9 and 1 specimens, respectively).

\section{DISCUSSION}

\section{Faunal distribution and beach morphodynamics}

Water percolation is the 'super parameter' controlling the interstitial environment of marine sandy beaches as it determines food inputs, oxygen levels, flow rates and general interstitial climate (Riedl and Machan, 1972; McLachlan, 1983). The patterns of water percolation and their effects on interstitial climate in beaches have been beautifully evaluated by Riedl and Machan (1972). On a uniform beach this interstitial climate would be uniform alongshore but show large changes across the intertidal zone, as investigated by several authors (for review see McLachlan, 1983). On beaches with alongshore variations in slope and grain size, however, water percolation changes considerably.

McLachlan et al. (1984) investigated this on Sorrento beach and showed that swash frequency on cusp horns was nearly twice that in bays. As a result of this, and the better drainage resulting from steeper slope and coarser sand, water input on a cusp hom $\left(1.06 \mathrm{~m}^{3} \mathrm{~m}^{-1}\right.$ $\left.\mathrm{h}^{-1}\right)$ was double that in a bay $\left(0.52 \mathrm{~m}^{3} \mathrm{~m}^{-1} \mathrm{~h}^{-1}\right)$. Although the interstitial system has been considered stable and complex relative to the sand surface layers inhabited by the macrofauna (McLachlan, 1983), it is clear that large variations occur. Zones of very high water input produce extreme pulsing currents (Riedl and Machan, 1972), strip microorganisms from sand grains (Munro et al., 1978) and may cause large changes in pore water content if they are followed by rapid drainage on coarse grained, steep cusp horns. This may be construed as a physically controlled extreme within the interstitial system. Bays are the opposite extreme and would represent a much more stable environment, except along the mid-axis which is dominated by the mini-rip backwash. The scouring effects of this rip current, and the pulsations in interstitial water flow it may cause, would appear to be the prime factors causing the slight drop-off in meiofauna numbers down the rip line. As effects of grain size and oxygen tensions can largely be removed, it therefore appears that the distribution of meiofauna in a cusp system is primarily determined by interstitial and surface water flow patterns. 
A great range of factors have been said to influence macrofauna community structure on sandy beaches. These include sand particle size, wave action, available food, sand moisture and dynamic changes due to storms. Of these, only sand particle size and beach slope have been quantitatively correlated with fauna (for review see McLachlan, 1983). The dynamic relation between wave action, grain size and beach slope (Davies, 1980; Wright and Short, in press) has been accepted as being largely responsible for faunal variations between different beaches, but its effects on longshore distribution within a single beach have been overlooked. Cusps, initiated by edge waves, provide pronounced longshore variations in both sedimentary and water flow parameters. The cusp horn corresponds to a more reflective condition while the bay, with its rip and delta, corresponds more closely to a low tide terrace intermediate type beach (Wright and Short, in press). As predicted from the regressions of McLachlan et al. (1981), the macrofauna as a whole increased in abundance in the bays (mean total $41 \mathrm{~m}^{-1}$ vs. $22 \mathrm{~m}^{-1}$ on horns) as slope flattened and sand particle size became finer. As the mean width of the occupied zone increased from 7 to $10 \mathrm{~m}$ from horns to bays, this represents a smaller increase in density than absolute abundance. However, highest densities of both bivalves were recorded in bays (Donacilla angusta $=$ $40 \mathrm{~m}^{-2}$, Donax faba $=20 \mathrm{~m}^{-2}$ )

There was, however, a secondary difference, the concentration of filter feeding bivalves in the bays and the more even distribution of the scavenging mole crab, Hippa australis. Concentration of bivalves in the bays may be due to 2 factors: (1) an accumulation there due to net swash flow in this direction, and their dependence on swash to move about the beach; (2) active preference for the bays where there is maximum feeding time and slower swash speeds. This can only be elucidated by experimentation. The more general feeding habits of $H$. australis and its greater ability to move about and burrow rapidly give it the freedom to roam the whole beach, concentrating in the upper swash zone where food is stranded. Although most wrack strands in the tops of bays, finer food particles may initially accumulate more on horns due to rapid infiltration of swash. This could explain the crabs' tendency to prefer horns during calm conditions. During storm events swash uprush is very strong and turbulent over the horns, and conditions may become too dynamic even for these crabs, particularly if the horns are also eroding.

On subtropical beaches in Natal, South Africa, where both filter feeding and scavenging mole crabs (Emerita austroafricana and Hippa adactyla, respectively) occur, the former are concentrated near the centres of large $\left(10^{2}\right.$ to $\left.10^{3} \mathrm{~m}\right)$ mega-cusp bays and the latter around horns where there is coarser sand (Dye et al., 1981). Most records of aggregations of Emerita spp. where cusps are present, report them in bays, or between bay centres and horns (Cubit, 1969; Perry, 1980). This suggests that the differential utilization of coarse/steep and fine/flat parts of beaches by scavengers and filter feeders, respectively, may have some functional significance, possibly related to food availability.

The 2 published papers on surf zone zooplankton both suggest that zooplankton distribution may be related to the wave-induced nearshore circulation system and, in particular, to the presence of rip currents and suspended food (Clutter, 1967; Wooldridge, 1983). Accurate sampling within dynamic areas like these after dark is difficult, and while large differences were found in this study between samples inside and outside the surf zone, samples within the surf zone showed less clear differences. Although there were significantly higher numbers off horns than bays during the second sampling, the reverse was found during the first sampling, but this was not significant. It would therefore appear that zooplankton is concentrated within the narrow surf zone, but that within this zone there are not very marked distribution patterns relating to different parts of the circulation system. If the zooplankton are being circulated within the surf zone, where the weak circulation takes the form of shoreward movement onto horns and seaward movement by rips off bays, then they would be expected to be moved towards homs and away from the rip heads. The high mobility of mysids and amphipods, however, makes this unlikely. We are rather inclined to regard the zooplankton as being fairly evenly distributed within the cusp surf zone.

From the sparse information available on fish communities of surf zones, it has been suggested that opportunists, which feed mainly on benthos or plankton, tend to dominate, but that the spatial distribution of fishes within surf zones is unknown (McLachlan. 1983). At Sorrento, benthos is more abundant in bays than horns, with approximately twice as many mean numbers per running metre, while zooplankton has less clear aggregations. For feeding purposes the shallow water in, and immediately adjacent to bays, provides a better area for fish than that off horns.

In the bay environment, violent wave breaking is dampened somewhat by the seaward return flow of the rip. In addition the rip head plume region exhibits the lowest flow velocities within the surf zone system, and therefore represents a more 'stable' environment for small fishes (i.e. schooling behaviour is enhanced). Further, the turbid conditions produced by suspended sediment within the plume may also serve to hide shoals of small fishes from predators. 


\section{CONCLUSIONS}

The beach/surf zone owes its character largely to incident wave energy, and most physical, chemical and biological processes on beaches are directly or indirectly driven by this energy in the form of water movement. Variation and infrastructure alongshore is generated by edge waves which probably initiate the formation of cusps and thereby engender a complex pattern of changes in an otherwise simple environment. The faunal spectrum shows a clear response to this. This response is primarily a response to differential water movement and variable grain size distribution which affects pore moisture, oxygen and flow rates, food availability and feeding time, locomotion and the avoidance of predators in the interstitial, macrobenthic and water column systems, respectively. Food chains in the beach/surf zone are not random or regular in spatial extent but aggregated in bays where most of the fauna are concentrated. The distribution of zooplankton on one occasion is the only exception to this. Rip currents, earlier suggested as influencing the distribution of surf zone animals (Clutter, 1967; McLachlan and Lewin, 1981; Wooldridge, 1983), have here been shown to be of prime importance in adding structural complexity to these environments. The surf zones studied here are, however, very small in extent and lack many features of larger, high energy systems such as rip channels, bars or megacusps.

While several faunal distributional correlations with beach morphodynamics have been demonstrated in this study, no cause and effect relationships have been proved. The concentration of bivalves in cusp bays for example, might be the result of active preference or differential sorting by the swash. While both reasons are appealing, the problem can only be resolved by experimentation. Similar questions can be raised about the avoidance of cusp horns by meiofauna and their decreased numbers under the rip line. The relation between fishes and rip heads can also be demonstrated but not explained by our data. Ecophysiological experimentation is needed to resolve this and to compare faunal response under other field conditions. In high energy beaches with rhythmic shorelines, lower energy areas adjacent to rip currents have steeper slopes than higher energy areas between rips which are subject to stronger wave swash. Thus swash/beach slope interactions are nearly opposite to those in reflective beach cusps and therefore offer an ideal opportunity for comparative study.

Acknowledgements. We thank Hester McLachlan, Alistar Robertson, Rod Lenanton, Dave Smith, June Horner, Jack Harding, Ray George and Shirly Slack-Smith for assistance and advice and the CSIRO and Department of Agriculture,
W.A., for providing facilities. We also thank Jill Thomas and Mrs A. J. Gerber for typing the manuscript and Liz Jefferson and Carmel Price for preparing the figures. A. McLachlan was funded by the South African CSIR, the University of Port Elizabeth and the CSIRO.

\section{LITERATURE CITED}

Bally, R. (1983). Factors affecting the distribution of organisms in the intertidal zones of sandy beaches. In: McLachlan, A., Erasmus, T. (ed.) Sandy beaches as ecosystems. Junk, The Hague, p. 391-403

Brown, A. C. (1971). The ecology of the sandy beaches of the Cape Peninsula, South Africa. Part 2: the mode of life of Bullia (Gastropoda). Trans. Soc. S. Afr. 39: 281-319

Chappell, J. (1978). On process-land form models from Papua New Guinea and elsewhere. In: Davies, J. L., Williams, M. A. J. (ed.) Landform evolution in Australasia. A. N. U. Press, Canberra, p. 348-361

Clutter, R. J. (1967). Zonation of nearshore mysids. Ecology 48: 200-208

Cubit, J. (1969). Behaviour and physical factors causing migration and aggregation of the sand crab Emerita analoga (Stimpson). Ecology 50: 118-123

Davies, J. L. (1980). Geographical variation in coastal development, 2 nd. ed. Longman, London

Dillery, D. G., Knapp, L. V. (1970). Longshore movements of the sand crab Emerita analoga (Decapoda, Hippidae). Crustaceana 18: 233-240

Dye, A. H., McLachlan, A., Wooldridge, T. (1981). The ecology of sandy beaches in Natal, South Africa. S. Afr. J. Zool. 16: $200-209$

Efford, I. E. (1965). Aggregation in the sand crab Emerita analoga (Stimpson). J. Anim. Ecol. 34: 63-75

Eliot, I. G., Clarke, D. J., Rhodes, A. (1982). Beach-width variation at Scarborough, Western Australia. J. R. Soc. West. Aust. 65: 153-158

Fricke, A. H., Fleming, B. W. (1983). Selective microhabitat colonisation by interstitial meiofauna as a function of grain size. In: McLachlan, A., Erasmus, T. (ed.) Sandy beaches as ecosystems. Junk, The Hague, p. 421-431

Grant, J. (1981). Sediment transport and disturbance on an intertidal sandflat: infaunal distribution and recolonisation. Mar. Ecol. Prog. Ser. 6: 249-255

Hill, G. W., Hunter, R. E. (1976). Interaction of biological and geological processes in the beach and nearshore environments, Northem Poole Island, Texas. In: Davis, R. A., Ethington, R. L. (ed.) Beach and nearshore sedimentation. Society of economic paleontologists and mineralogists. Tulsa, Oklahoma, Spec. Publ. 24: 169-187

Hodgkin, E. P., di Lollo, V. (1958). The tides of southwestern Australia. J. R. Soc. West. Aust. 41:42-54

Inman, D. L., Guza, R. T. (1982). The origin of swash cusps on beaches. Mar. Geol. 49: 133-148

Lasiak, T. A. (1982). Structural and functional aspects of the surf zone fish community in the Eastern Cape. Ph. D. thesis, University of Port Elizabeth

McLachlan, A. (1983). Sandy beach ecology: a review. In: McLachlan, A., Erasmus, T. (ed.) Sandy beaches as ecosystems. Junk, The Hague, p. 321-380

McLachlan, A., Eliot, F. G., Clarke, D. J. (1984). Water filtration by reflective microtidal beaches and shallow sublittoral sands and its implications for a lagoon ecosystem in western Australia. Estuar. coast. Shelf Sci. (in press)

McLachlan, A., Lewin, J. (1981). Observations on surf phyto- 
plankton blooms along the coasts of South Africa. Botanica mar. 24: 553-557

McLachian, A., Wooldridge, T., Dye, A. H. (1981). The ecology of sandy beaches in Southern Africa. S. Afr. J. Zool. 16: 219-231

Munro, A. L. S., Wells, J. B. J., McIntyre, A. D. (1978) . Energy flow in the flora and meiofauna of sandy beaches. Proc. R. Soc. Edinb. 76 B: 297-315

Perry, D. M. (1980). Factors influencing aggregation patterns in the sand crab Emerita analoga (Crustacea: Hippidae). Oecologia (Berl.) 45: 379-384

Riedl, R. J., Machan, R. (1972). Hydrodynamic patterns in lotic intertidal sands and their bioclimatological implications. Mar. Biol. 13: 179-209

Short, A. D. (1979). Three dimensional beach stage model. J. Geol. 87: 553-571

Short, A. D., Hesp, P. A. (1982). Wave, beach and dune interactions in southeastern Australia. Mar. Geol, 48: $259-284$
Sokal, R. R., Rohlf, F. J. (1969). Biometry. W. H. Freeman, San Francisco

Steedman, R. K. \& Associates. (1977). Mullaloo marina environmental investigations. Part 1. Physical oceanographic studies. Report to Wanneroo Shire Council, Perth, W. Australia, p. 1-210

Wooldridge, T. (1983). Ecology of beach and surf zone rnysid shrimps in the Eastern Cape, South Africa. In: McLachlan, A., Erasmus, T. (ed.) Sandy beaches as ecosystems. Junk, The Hague, p. 449-460

Wright, L. D., Chappell, J., Thom, B. G., Bradshaw, M. P., Cowell, P. (1979). Morphodynamics of reflective and dissipative beach and inshore systems: Southeastern Australia. Mar. Geol. 32: 105-140

Wright, L. D., Short, A. D. (in press). Morphodynamics of beaches and surf zones in Australia. In: Komar, P. D. (ed.) Handbook of coastal processes and erosion, CRC Press, Corvallis

This paper was presented by Professor J. G. Field; it was accepted for printing on April 28, 1984 